\title{
Effect of maize stalk processing methods on fattening bulls and on diet digestibility
}

\author{
X.-X. Su1, H.-Y. Liu, H.-W. Qi, W. Yu and Q. Chen \\ Branch of Animal Science, Jilin Academy of Agricultural Sciences \\ Gongzhuling 136100, P.R. China
}

\begin{abstract}
The experiment was conducted to determine the effect of maize stalk processing methods on fattening bulls and on diet digestibility. Thirty crossbred bulls were randomly divided into six groups that were fed cut stalk, rolled cut stalk, baled stalk, stalk pellets, stalk blocks, stalk sticks, respectively. The results showed: 1 . feed intake was highest in the last three maize stalk groups, lowest in the cut stalk group, 2. the digestibility of the stalk pellet was lower than the other forms, 3 . daily gains were highest in the stalk block and stalk stick groups, lowest in the cut stalk group.
\end{abstract}

KEY WORDS: maize stalk, processing methods, digestibility, fattening bulls

\section{INTRODUCTION}

In the northern regions of China most ruminants rely generally on maize stalk as a roughage source. Due to its loose texture, poor palatability and low nutritive value (Ranjhan and Pathak, 1979), many processing methods have been developed to improve its intake and digestibility. In recent years, numerous stalk processing enterprises have emerged to market stalk products in different physical forms such as stalk pellets, blocks, and compressed bales. The objectives of this experiment were to study the effect of maize stalk processing methods on fattening bulls and on diet digestibility and to provide technical references both for selection of stalk products for fattening-bull breeders and for determination of processing methods for stalk processing enterprises.

\footnotetext{
${ }^{1}$ Corresponding author: e-mail: liuhai1276@163.com
} 


\section{MATERIAL AND METHODS}

\section{Experimental animals}

Thirty crossbred bulls (Simmental $\times$ Chinese Yellow cow, 18 months old and $336 \pm 20.5 \mathrm{~kg}$ liveweight) were divided into 6 treatments. They were housed individually and fed twice daily (08.00 and 16.00) .

\section{Experimental diets}

The experiment was conducted with a randomized block design involving six experimental diets. For the experiment, the nutrient content of the diet complied exactly with the Feeding Standards for Beef Cattle in China (2004). All diets contained $5.5 \mathrm{~kg}$ maize distiller's grain and $3.92 \mathrm{~kg}$ concentrate mixture. They were supplemented with maize stalk in different physical forms. The six maize stalk forms (Table 1) were: 1 . stalk compressed bale (SCB): maize stalks were cut and rolled, then compressed into bales; 2 . stalk pellets (SP): maize stalks were cut and crushed, then extruded into pellets; 3 . stalk blocks (SB): maize stalks were cut and extruded into blocks; 4 . stalk sticks (SS): maize stalks were cut and extruded into columns; 5. cut stalk (CS): maize stalks were cut only; 6 . rolled and cut stalk (RCS): maize stalks were cut, and rolled into filaments. The first four maize stalks were made using new processing methods, the last two are commonly used by farmers. The stalk above was from Jidan 136 variety maize.

Table 1. Processing methods and physical forms of maize stalks

\begin{tabular}{llllcc}
\hline Group & Methods & $\begin{array}{l}\text { Name of } \\
\text { products }\end{array}$ & \multicolumn{1}{c}{ Shape } & $\begin{array}{c}\text { Density } \\
\mathrm{g} / \mathrm{cm}^{3}\end{array}$ & $\begin{array}{c}\text { Particle size, } \\
\mathrm{mm}\end{array}$ \\
\hline SCB & $\begin{array}{l}\text { Rolled and } \\
\text { compressed into } \\
\text { bales }\end{array}$ & $\begin{array}{l}\text { Stalk } \\
\text { compressed } \\
\text { bale }\end{array}$ & $\begin{array}{l}\text { Rectangle or square } \\
(500 \times 50500 \mathrm{~mm})\end{array}$ & $0.35-0.50$ & $5-10 \times 30-300$ \\
SP & $\begin{array}{l}\text { Ground and } \\
\text { pelleted }\end{array}$ & Stalk pellet & $\begin{array}{l}\text { Columnar (diameter } \\
8 \text { mm, naturally broken) }\end{array}$ & $0.60-1.00$ & $0.1-1 \times 1-5$ \\
& $\begin{array}{l}\text { Ground and } \\
\text { formed into } \\
\text { blocks }\end{array}$ & Stalk block & $\begin{array}{l}\text { Square }(30 \times 30 \mathrm{~mm}, \\
\text { naturally break) }\end{array}$ & $0.45-0.70$ & $1-5 \times 5-10$ \\
SB & Stalk stick & $\begin{array}{l}\text { Columnar (diameter } 70 \\
\text { mm, naturally broken) }\end{array}$ & $0.45-1.00$ & $2-10 \times 5-10$ \\
SS & $\begin{array}{l}\text { Ground and } \\
\text { formed into sticks }\end{array}$ & Lut stalk & Loose & ND & $10-30 \times 15-30$ \\
C1 & Cut only & $\begin{array}{l}\text { Rolled and } \\
\text { cut stalk }\end{array}$ & Loose & ND & $5-10 \times 30-300$ \\
C2 & Rolled and cut & & & \\
\hline
\end{tabular}

ND: not determined 


\section{Measurements and sampling}

Feeding trial. The experimental periods were $90 \mathrm{~d} ; 10 \mathrm{~d}$ were for dietary adaptation. The feeding procedure was: maize stalks were soaked in $0.5 \% \mathrm{NaCl}$ solution for $12 \mathrm{~h}$, then mixed with concentrate and maize distiller's grain fed at a fixed level, stalk pellets, stalk blocks and stalk sticks were fed at a restricted level avoiding excess intake by the animals, and cut stalk, rolled and cut stalk, and stalk bales were fed ad libitum. To monitor performance, feed intake of each group was measured daily and body weight was measured once every $15 \mathrm{~d}$ prior to feeding in the morning.

Digestion trial. Total faeces were collected to determine apparent digestibility of nutrients over 6 days (from days 31 to 36). During the collection period, the feeds offered and refused and faeces were recorded daily. Samples of feeds and faeces were taken daily and then pooled for the whole collection period. Dry matter content of feeds offered and refused and of faeces from individual bulls was determined daily. Samples of feeds, refusals and faeces were analysed for crude protein $(\mathrm{CP})$, ether extract $(\mathrm{EE})$, crude fibre $(\mathrm{CF})$, nitrogen-free extractives (NFE) and ash.

\section{Statistical analysis}

The results were analysed with one-way ANOVA by SPSS (Statistical Analysis Software, SPSS Institute Inc., USA). Means values were compared using a least significant difference test.

\section{RESULTS}

The results of the feeding trial are summarized in Tables 2 and 3. The maize stalk processing methods had a significant effect on the growth performance of fattening bulls. Feed intake (DMI) and nutrient ingestion in groups SP, SB and SS were highest, followed by groups SCB and C2, lowest in group C1. The average daily gain in groups $\mathrm{SB}$ and $\mathrm{SS}$ was similar, but significantly higher than in groups $\mathrm{SCB}$, SP and $\mathrm{C} 2(\mathrm{P}<0.05)$, and higher than in group $\mathrm{C} 1(\mathrm{P}<0.01)$. Furthermore, the average daily gain of groups $\mathrm{SCB}, \mathrm{SP}$ and $\mathrm{C} 2$ groups was higher compared with group $\mathrm{C} 1(\mathrm{P}<0.05)$. 
Table 2. Feed intake and nutrient ingestion in cattle fed different forms of maize stalk

\begin{tabular}{lcccccc}
\hline \multirow{2}{*}{ Group } & DMI & \multicolumn{5}{c}{ Nutrient ingestion, g/head · d } \\
\cline { 3 - 7 } & $\mathrm{kg} / \mathrm{head} \cdot \mathrm{d}$ & $\mathrm{CP}$ & $\mathrm{EE}$ & $\mathrm{CF}$ & $\mathrm{NFE}$ & ash \\
\hline SCB & 8.789 & 1063 & 294 & 1958 & 4795 & 679 \\
SP & 10.287 & 1170 & 309 & 2484 & 5517 & 807 \\
SB & 10.287 & 1164 & 310 & 2507 & 5503 & 803 \\
SS & 10.297 & 1164 & 308 & 2496 & 5535 & 794 \\
C1 & 8.527 & 1044 & 290 & 1853 & 4687 & 652 \\
C2 & 8.848 & 1065 & 294 & 1961 & 4847 & 681 \\
P & 0.061 & 0.058 & 0.124 & 0.057 & 0.148 & 0.115 \\
SEM & 0.053 & 2.500 & 1.555 & 3.354 & 4.301 & 1.581 \\
\hline
\end{tabular}

Table 3. Average daily gain of cattle fed different forms of maize stalk

\begin{tabular}{lccc}
\hline Group & $\begin{array}{c}\text { Initial weight } \\
\mathrm{kg}\end{array}$ & $\begin{array}{c}\text { Final weight } \\
\mathrm{kg}\end{array}$ & $\begin{array}{c}\text { Average daily } \\
\text { weight gain, } \mathrm{g}\end{array}$ \\
\hline SCB & $334.84 \pm 45.14$ & $436.81 \pm 28.31$ & $1153^{\mathrm{b}} \pm 164$ \\
SP & $342.62 \pm 37.26$ & $445.76 \pm 32.56$ & $1146^{\mathrm{b}} \pm 286$ \\
SB & $338.37 \pm 32.78$ & $460.41 \pm 29.87$ & $1356^{\mathrm{Aa}} \pm 178$ \\
SS & $328.80 \pm 38.54$ & $453.81 \pm 31.34$ & $1389^{\mathrm{Aa}} \pm 193$ \\
C1 & $347.42 \pm 37.77$ & $438.22 \pm 24.16$ & $1009^{\mathrm{Bc}} \pm 212$ \\
C2 & $332.60 \pm 42.36$ & $437.36 \pm 27.07$ & $1163^{\mathrm{b}} \pm 257$ \\
P & 0.675 & 0.237 & 0.002 \\
SEM & 9.5158 & 11.2323 & 49.2476 \\
\hline
\end{tabular}

values are presented as mean $\pm \mathrm{SD}$; a-q - means with different superscripts in a column differ significantly $(\mathrm{P}<0.05)$; A-Q - means with different superscripts in a column differ significantly $(\mathrm{P}<0.01)$

The digestibility coefficients are shown in Table 4 . The digestibility of DM, CP, $\mathrm{CF}$ and NFE in group SP was significantly lower $(\mathrm{P}<0.01)$ than in other groups, in which no differences were found in the digestibility of any nutrients.

Table 4. Digestibility of feed in cattle fed different forms maize stalk, $\%$

\begin{tabular}{lcccccc}
\hline Group & DM & CP & EE & CF & NFE & Ash \\
\hline SCB & $64.72^{\mathrm{A}} \pm 3.82$ & $64.98^{\mathrm{A}} \pm 5.17$ & $71.96 \pm 3.96$ & $61.33^{\mathrm{A}} \pm 5.18$ & $71.00^{\mathrm{A}} \pm 4.96$ & $26.56 \pm 5.32$ \\
SP & $55.26^{\mathrm{B}} \pm 2.76$ & $50.68^{\mathrm{B}} \pm 4.21$ & $73.33 \pm 3.51$ & $50.29^{\mathrm{B}} \pm 4.88$ & $61.30^{\mathrm{B}} \pm 2.81$ & $29.02 \pm 7.62$ \\
SB & $62.90^{\mathrm{A}} \pm 3.62$ & $63.54^{\mathrm{A}} \pm 4.59$ & $74.82 \pm 3.94$ & $61.01^{\mathrm{A}} \pm 5.10$ & $68.19^{\mathrm{A}} \pm 4.82$ & $28.15 \pm 5.33$ \\
SS & $63.51^{\mathrm{A}} \pm 2.78$ & $62.11^{\mathrm{A}} \pm 3.12$ & $77.31 \pm 4.26$ & $59.29^{\mathrm{A}} \pm 3.94$ & $70.21^{\mathrm{A}} \pm 2.97$ & $31.32 \pm 7.12$ \\
C1 & $65.40^{\mathrm{A}} \pm 3.26$ & $65.39^{\mathrm{A}} \pm 3.55$ & $75.32 \pm 4.26$ & $62.13^{\mathrm{A}} \pm 3.62$ & $71.22^{\mathrm{A}} \pm 3.15$ & $26.19 \pm 4.26$ \\
C2 & $65.64^{\mathrm{A}} \pm 3.55$ & $66.10^{\mathrm{A}} \pm 4.58$ & $73.04 \pm 4.36$ & $60.52^{\mathrm{A}} \pm 3.11$ & $72.87^{\mathrm{A}} \pm 3.87$ & $25.03 \pm 4.33$ \\
P & 0.01 & $<0.001$ & 0.134 & $<0.001$ & $<0.001$ & 0.156 \\
SEM & 1.4027 & 0.8314 & 0.7491 & 0.8263 & 0.8950 & 0.5402 \\
\hline
\end{tabular}

${ }^{\mathrm{AB}} \mathrm{P}<0.01$ 


\section{DISCUSSION}

The quality of feed is one of the factors affecting its intake by animals, however, physical characteristics of feed seem to be a more influential factor (Raghavendra et al., 2006). In this experiment, poor palatability of maize stalk in group $\mathrm{C} 1$ resulted in lower feed intake and nutrient ingestion than in other groups, at the same time, many hard parts were left in the manger. Feed intake in groups SCB and C2, which received stalks that were soft without hard materials because they were rolled, was higher than in group C1. It was found that bulls in groups SP, SB, SS also had a good appetite for maize stalk when they were full. This could be due to the better possibility for selection (Bosman et al., 1995; Van and Ledin, 2002) for the softness and palatability of maize stalk in groups SP, SB, SS group improved after cutting and extrusion. In order to avoid overfeeding the bulls in these groups, feed intake was controlled according to Feeding Standards for Beef Cattle in China (2004).

Digestibility of DM, CP, CF and NFE in group SP was significantly lower than in the other groups. The authors considered that the retention time of maize stalk in the rumen was so short that the rumen flora could not make full use of it because the particle size was too small (Feng, 2004). This result is in agreement with Thomas et al. (1979).

\section{CONCLUSIONS}

It can be concluded that extruding and rolling of poor quality roughage like maize stalk had a definite advantage in terms of improving growth performance by increasing feed intake.

\section{REFERENCES}

Bosman H.G., Versteegden C.J.G.M., Odeyinka S.M., Tolkamp B.J., 1995. Effect of amount offered on intake, digestibility and value of Gliricidia sepiun and Leucaena leucocephala for West African Dwarf goats. Small Ruminant Res. 15, 247-256

Feeding Standards for Beef Cattle, 2004. Ministry of Agriculture of Republic of China, Beijing, pp. 11

Feng Y.L., 2004. Ruminant Nutrition. Scientific Technology Publishing Housing. Beijing, pp. 329-358

Raghavendra B., Vijay K., Manpal S., Khub S., 2006. Energy expenditure in crossbred cattle fed paddy straw of different form. Asian-Austr. J. Anim. Sci. 19, 1755-1760

Ranjhan S.K., Pathak N.N., 1979. Average nutritive value of common feeding stuffs. In: Management and Feeding of Buffaloes. Vikas Publishing House, New Delhi, pp. 255-256

Thomas P.C., Kelly N.C., Wait M.K., 1976. The effect of physical form of a silage on its voluntary consumption and digestibility by sheep. Grass Forage Sci. 31, 19-22

Van D.T.T., Ledin I., 2002. Effects of different foliages and sugar cane in the diet in late pregnancy on ewe and lamb performance. Asian-Austr. J. Anim. Sci. 15, 828-833 